\title{
A modéstia dos filósofos
}

Hermas Gonçalves Arana

Professor da FE/Unicamp

\section{Resumo}

O artigo levanta questões que interessam ao tema do magistério filosófico: o sentido original do conceito de filosofia, sua realização peculiar no método pedagógico de Sócrates, a ideia da filosofia como saber e como ciência. É a filosofia, para o professor e para o aluno, principalmente busca ou aquisição? $\mathrm{O}$ artigo considera, neste contexto, a magnitude do empreendimento filosófico e, por outro lado, as possibilidades da razão humana, que as filosofias mesmas diversamente tematizam.

Palavras-chave: Filosofia; Filósofos; Saber.

\section{Resumen}

El artículo plantea cuestiones que interesan al magisterio filosófico: el sentido original del concepto de filosofía, su realización peculiar en el método de Sócrates, la idea de la filosofía como saber y como ciencia. Es la filosofía, para el profesor y para el alumno, principalmente búsqueda o adquisición? El artículo considera, en este contexto, la magnitud del emprendimiento filosófico $y$, por otro lado, las posibilidades de la razón humana, que las mismas filosofías diversamente tematizan.

Palabras-clave: Filosofía; Filósofos; Saber. 


\section{Introdução}

$\Lambda_{\text {dizer: aquele que ama a sabedoria. }}$ Reza a tradição, apoiada em Diógenes Laércio e Cícero (Diógenes Laêrtios, 1977; 1, 12; Cícero, 1931, p. 5, cap. 3, §§ 7-9), que o primeiro a empregar o termo filósofo, aplicando-o, aliás, a si mesmo, é Pitágoras de Samos (século VI a.C., segunda metade) ${ }^{1}$. Conforme Diógenes Laércio e Cícero (conforme Heráclido do Ponto, em que estes dois autores declaram basear-se), Leão, tirano da cidade de Fliunte, entusiasmado com a eloquiência e com o gênio de Pitágoras, ter-lhe-ia perguntado certa feita qual especialmente a arte ou a ciência de que ele, Pitágoras, teria seguro conhecimento. Pitágoras: - Nenhuma, eu sou um filósofo. - Mas, que é um filósofo e em que se distingue dos demais homens? - teria insistido o soberano. Evocando os Grandes Jogos, aonde alguns iam para competir, outros para negociar, outros simplesmente para ver (os primeiros em busca de glória, os segundos em busca de lucro, os últimos - "os melhores" apenas pelo gosto de acompanhar com a máxima atenção possível o que acontecia), teria respondido Pitágoras que assim também na vida de todos nós. Os filósofos, ávidos do conhecimento, se assemelhariam aos do terceiro grupo: seriam aqueles que não trocariam por nada deste mundo a vida contemplativa ( $\theta \varepsilon \omega \rho \eta \tau \imath \kappa o \varsigma ~ \beta i ́ o \varsigma)$, o estudo teórico da natureza - por nada deste mundo, enfim, a sabedoria, de que eram cultores e amantes, apaixonados (Diôgenes Laêrtios, 1977, p. VIII, 8)².

\footnotetext{
${ }^{1}$ Heráclito de Éfeso teria a precedência cronológica, embora usando a palavra na forma adjetiva: "É necessário que os homens filósofos sejam bons investigadores de muitas coisas" - fragmento B 35 (DIELS, H.; KRANZ, W., 1952) -, mas discute-se a autenticidade deste fragmento. De qualquer modo, o testemunho de Heráclido Pôntico, referido por nós a seguir, também é suspeito: discípulo estimado de Platão - chega a substituí-lo, quando da sua viagem a Siracusa, na direção da Academia -, Heráclido projetaria sobre o passado, sobre Pitágoras, a noção platônica de filosofia. Ver, por exemplo, BURKERT, W., 1960: 159-177. Posição também de Krug, Zeller... Ou seja, é possível que Pitágoras e Heráclito não tenham conhecido a palavra filosofia e seus cognatos. É possível que tais palavras só tenham aparecido no século $\mathrm{V}$ a.C..

${ }^{2}$ Esta tríplice divisão da vida humana e suas ocupações vamos reencontrar em Platão (República, IX, 581-583), em Aristóteles (Ética a Nicômaco, 1.5. 1095 b 14)...
} 
Cultores, amantes da sabedoria..., mas não, propriamente, sábios. Dizendo "sou um filósofo", Pitágoras estaria dizendo: "Sábio eu não sou; esforço-me na direção da sabedoria, anseio por ela, amo-a ( $\varphi \imath \lambda \varepsilon \dot{\varepsilon} \omega$, um dos verbos gregos para amar), mas não a possuo". Sábio, бoழós, esclarece o escritor Cícero, denomina-se na Antiguidade aquele que conhece as coisas divinas e humanas, os princípios e as causas de todas as coisas. Homem algum é sábio - teria dito Pitágoras -; sábio somente Deus (Diôgenes Laêrtios, I, 12) ${ }^{3}$.

Por quanto tempo, na história da filosofia, a idéia de filosofia guardará intactos os componentes da concepção original? Morente, após referir-se a ela, ao significado primeiro, etimológico, da palavra filosofia, diz, repetindo o que admitem quase todos os historiadores da filosofia:

Este significado dura na história pouco tempo. Em Heródoto, em Tucídides, talvez nos pré-socráticos, uma ou outra vez, durante pouco tempo, tem este significado primitivo de amor à sabedoria. Imediatamente passa a ter outro significado: significa a própria sabedoria. De modo que, já nos primeiros tempos da autêntica cultura grega, filosofia significa não o simples afã ou o simples amor à sabedoria, mas a própria sabedoria (Morente, 1970, p. 26) ${ }^{4}$,

variando, acrescentaríamos nós, a ênfase, que mais e mais recai ou sobre o lado teórico do conceito (conhecimento do mundo) ou sobre o lado prático (aptidão, capacidade para bem se conduzir na vida e ser feliz) - o verdadeiro e o bom ${ }^{5}$.

\footnotetext{
${ }^{3}$ Cf. Platão, Fedro 278 c-d ("Penso que a designação sábio, Fedro, seria excessiva, cabendo exclusivamente a um deus. Mas o nome filósofo, ou algo semelhante, se lhe ajustaria melhor e lhe seria mais conveniente"); Banquete, 204 ("Nenhum deus ama a sabedoria [filosofa] ou deseja ser tornado sábio. Já o é. E ninguém mais que já é sábio ama a sabedoria [filosofa]. Tampouco o ignorante ama a sabedoria [filosofa] ou deseja ser tornado sábio").

${ }^{4}$ Note o leitor as cláusulas restritivas "talvez nos pré-socráticos", "uma ou outra vez", "durante pouco tempo"... As passagens de Heródoto e Tucídides, que Morente menciona, são as seguintes: "Ouvimos muitas coisas a teu respeito, hóspede ateniense, em relação à tua sapiência [sophiês] e às tuas perambulações, e a quantas terras foste em busca de conhecimento [philosopheôn]" - frase que, segundo Heródoto, o rei da Líbia dirige a Sólon, recém-chegado do Egito (Herôdotos, 1988: I,30); "Amamos a beleza sem exageração; amamos a sabedoria [filosofamos] sem timidez" - trecho da célebre oração fúnebre de Péricles em que o líder ateniense elogia o modo democrático de vida praticado naquela cidade (Thucydides, 1999: II, 40, 1).
}

${ }^{5}$ Quanto aos diversos sentidos que o termo filosofia assume na Antiguidade grega ver Malingrey, 1961. 
De qualquer modo, é possível harmonizar a tese das limitações humanas com a tese da posse da sabedoria: basta afirmar a posse em termos, fazendo, aliás, do próprio reconhecimento dos limites um sinal da sabedoria. Maritain:

A modéstia de Pitágoras é muito sábia, pois que a profundeza e a dificuldade das verdades supremas, assim como a fraqueza da natureza humana, "escrava sob tantos pontos de vista", são causa de que a sabedoria "não seja um bem recebido pelo homem a título de posse" ou de propriedade, isto é, um bem que ele possa empregar de modo inteiramente livre: por causa das múltiplas necessidades a que tem de submeter-se, o homem possui-a apenas a título precário; de sorte que somos muito menos sábios, do que mendigos de sabedoria. Entretanto, uma coisa é certa: que a Filosofia é a própria sabedoria, tal qual convém à natureza humana (Maritain, 1987, p. 19).

\section{Do modesto Pitágoras}

Interessante que os expositores do assunto, trazendo à baila a resposta de Pitágoras, tomem quase sempre esta resposta como expressão da modéstia de Pitágoras. Assim, o dicionarista Lalande: "Este [Pitágoras], por modéstia, teria declarado 'artem quidem se scire nullam, sed esse philosophum'..." (Lalande, 1996, p. 407). O dicionarista Littré: “Ele [Pitágoras] é o primeiro a se fazer chamar filósofo; antes dele, os homens que se devotam à contemplação da natureza levam o nome de sábios; Pitágoras, por modéstia, toma o de filósofo" (Littré, 1889, p. 3, 4672). Franca, historiador da filosofia: “A Pitágoras, como refere Cícero, remonta a origem do termo 'filósofo', que ele, por evitar o de sábio - бópos [sic] -, modestamente se atribuía, chamando-se amigo da sabedoria" (Franca, 1973, p. 44). Kenny, igualmente historiador da filosofia: "Atribui-se a ele [Pitágoras] a invenção da palavra 'filosofia`, na ocasião em que, em vez de declarar-se um sábio, ou homem de saber (sophos), ele disse com modéstia ser apenas um amante da sabedoria (philosophos)"(Kenny, 2008, p. 33). Magalhães-Vilhena: "Por modéstia, diz a tradição, Pitágoras teria afirmado não possuir propriamente um conhecimento seguro de qualquer ciência, e por isso não ser um 'sábio', mas apenas um 'amigo do saber', um filósofo" (Magalhães-Vilhena, 1977, p. 38). 
Interessante, reiteramos nós, porque, dependendo do que se entenda por modestamente, modéstia e modesto, sempre é possível perguntar como sabem estes expositores que Pitágoras, ao dizer o que diz, está sendo modesto. Afinal (comecemos pelo mais rapidamente apreensível) isto não consta de modo explícito em nenhum dos documentos originais. É preciso inferir - e inferir, além de inevitável, é perigoso. Dizer, sem mais aquela, que as palavras de Pitágoras são um sinal da sua modéstia pode ser, dependendo do que signifique este nome, um imenso escorregão no trato exegético do texto. Afinal, uma das acusações muito comuns, feita aos que se ocupam em filosofar, é justamente a da presunção, a da altivez, a da imodéstia. Não declara o mesmo Pitágoras que os homens do terceiro grupo são "os melhores", ?

Por outro lado, admitir que as palavras de Pitágoras "não sou um sábio" exprimem a modéstia do filósofo, que somente à luz desta condição o verdadeiro sentido daquelas palavras se revela, implicaria admitir que efetivamente (modéstia à parte...) Pitágoras se considera um sábio ou que o devamos considerar assim? O filósofo, depois de tudo, segundo Pitágoras, é ou não é aquele que sabe, aquele que sabe em profundidade, aquele que domina teoricamente "os princípios e as causas de todas as coisas"?

Melhor começarmos pela definição dos conceitos. Que quer dizer modéstia?

Os dicionários da língua portuguesa, do Bluteau ao nosso Houaiss, distinguem três blocos de sentidos, parcialmente sobrepostos, no que diz respeito à palavra modéstia (do latim modestǐa, e este ligado a mǒdus e modǐcus):

a. despretensão;

b. reserva, pudor, compostura;

c. moderação, sobriedade, comedimento, temperança.

\footnotetext{
${ }^{6}$ Fiquemos em Heráclito, contemporâneo de Pitágoras: "Era mais altivo que qualquer outro homem e olhava para todos com desdém"... "Quando jovem, costumava dizer que não sabia coisa alguma, porém, chegando à idade adulta, passou a afirmar que havia aprendido tudo"... (Diôgenes Laêrtios, 1977: IX, 1, 5).
} 
Presente em qualquer destes sentidos a idéia de limite e de medida. Mǒdus: medida; medida que não se deve ultrapassar; maneira adequada de proceder, de expressar-se. Modǐcus: que está na medida; proporcionado; moderado; médio, mediano, medíocre (mas medíocre tem conotação pejorativa em português...). Moderor é manter na medida, moderar, regular, restringir, diminuir (“moderar a ira", "moderar as palavras"...).

Vê-se que o termo modéstia e seus derivados podem referir-se tanto à pessoa do filósofo quanto ao tamanho das suas ambições teóricas - seja o alcance, seja a importância das teses que o filósofo defende -, e é com esta destinação aberta do conceito que o filósofo e sua obra, muitas vezes, se oferecem ao leitor, complicando nossa exposição do assunto.

De qualquer modo os dicionários de filosofia não consagram um verbete à palavra modéstia. O máximo que teríamos aí seria a expressão técnica modéstia socrática, que vamos agora considerar pelas achegas que esta análise, embora rápida, pode trazer à discussão do conceito.

\section{Da modéstia socrática}

Sabemos que os primeiros filósofos, os que vêm antes de Sócrates e dos sofistas, estudam a physis ( $(v \dot{\sigma} \varsigma \varsigma$ ), a natureza. São chamados físicos ou naturalistas. Impressionados com a transitoriedade, a constante renovação das coisas, saem em busca das suas bases primordiais, seus princípios unificadores. Quais são eles? Como atingi-los? Como expressá-los? Os diferentes conceitos de ser e devir, que despontam, visam a tornar compreensível o processo cósmico - matéria e vida -, sua gênese, seu desenvolvimento, sua espantosa diversidade.

No início, ainda influenciado pelo mestre Arquelau (justamente cognominado “O Naturalista”), Sócrates dedica-se à filosofia da physis:

Quando eu era jovem experimentava um vivo e extraordinário interesse pelo saber que chamam de investigação da natureza. Julgava formidável conhecer as causas de tudo, o porque cada uma das coisas vinha a ser, o porque de seu perecimento e o porque da sua existência (Platão, Fédon: $96 a)^{7}$.

\footnotetext{
${ }^{7}$ A gramática do texto em português não é por nossa conta. Isto vale para todas as citações que fazemos, quando a tradução não é nossa.
} 
Em algum momento, contudo, da sua evolução espiritual, quer de modo repentino, quer gradualmente, Sócrates afasta-se dos estudos naturais, que, diga-se a propósito, nunca fizeram parte dos seus ensinamentos públicos (Platão, Apologia, 19 c,d).

Tal como os sofistas, Sócrates volta-se, então, para o homem, para o homem que os filósofos naturalistas deixam na penumbra: o homem-sujeito, o homem e suas criações espirituais, o homem e a cultura... Inicia-se o período chamado humanista da filosofia antiga.

Tal como os sofistas, além disto, Sócrates afasta-se desiludido das inconciliáveis, desencontradas afirmações que os filósofos físicos sustentam, um após o outro, em suas arrojadas elaborações teóricas.

Quanto aos que se preocupam com a natureza do universo, estes afirmam a unidade do ser, aqueles sua multiplicidade infinita. Uns crêem os corpos em perpétuo movimento, outros em inércia absoluta. Aqui se pretende que tudo nasce e tudo morre, ali que nada se criou e nada deve ser destruído (Xenofonte, 1980, p. I, 1, 150) ${ }^{8}$.

Este estado de coisas (esta diaphonía, dirão os cépticos mais tarde) Sócrates atribui ao seguinte: o homem não deve indagar, não deve procurar conhecer o que excede o domínio do conhecimento humano possível. Assim, a ciência física, segundo a concebem os filósofos da physis, é inacessível ao homem. Tanto erra aquele que consulta os oráculos sobre o que está facultado ao homem conhecer por si mesmo, como erra aquele que, por si mesmo, busca o conhecimento, a posse intelectual, de tudo quanto efetivamente foge à alçada dos recursos humanos. Arrogar-se o que somente à divindade compete, mesmo tão-só desejá-lo, diz Sócrates, além de heresia é insensatez e loucura.

Abstendo-se [Sócrates], ao revés da maioria dos outros filósofos, de dissertar sobre a natureza do universo, de indagar a origem espontânea do que os sofistas chamam "cosmos" e a que leis fatais obedecem os fenômenos celestes, ia a ponto de mostrar a loucura dos que vacam a semelhantes especulações. Antes de tudo examinava se eles presumiam ter aprofundado suficientemente os conhecimentos humanos para se ocuparem de tais

\footnotetext{
${ }^{8}$ Reconhece o leitor nesta citação os eleatas, os atomistas, Heráclito e seus seguidores...?
} 
assuntos, ou se achavam razoável pôr de parte o que está ao alcance do homem para intrometer-se no que aos deuses pertence. Admirava-se de que não vissem serem tais segredos intangíveis ao homem, de vez que, longe de concordarem entre si, aqueles mesmos que se gabam de melhor falar sobre eles se têm mutuamente na conta de loucos (Xenofonte, 1980, p. I, 1, 12$14)^{9}$.

Em geral interdizia [Sócrates] o preocupar-se excessivamente dos corpos celestes e das leis segundo as quais os dirige a divindade. Havia estes segredos por impenetráveis aos homens e considerava ofensa aos deuses sondar os mistérios que não lhes aprouver revelar-nos. Aditava que, enfronhando-se em tais especulações, corria-se o risco de perder a razão, como a perdera Anaxágoras com suas cerebrações para explicar os mecanismos divinos (Xenofonte, 1980, p. IV, VII, 6).

Aliás, o tema da loucura, associada à falta da modéstia intelectual do sujeito conhecedor, associada ao exagero, à magnificação indevida das medidas racionais do homem, reaparece em outros autores da Antiguidade grega. Aristóteles acusa os eleatas - Melisso em particular - de beirarem a loucura, a loucura da razão que não conhece seus limites... (Aristóteles, 2001, p. 72) ${ }^{10}$.

Em que consiste, neste contexto, a modéstia socrática?

A modéstia socrática é um aspecto fundamental do método socrático, que se caracteriza basicamente de dois modos.

Comecemos pela ironia.

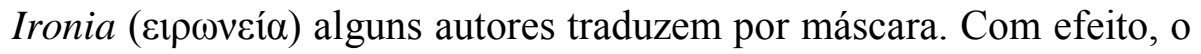
verbo grego correspondente significa dissimular, seja no sentido de fingir, seja no de esconder. A máscara simula e encobre. A máscara disfarça.

Diferentemente dos sofistas, Sócrates apresenta-se a seu interlocutor (nunca às massas!) como quem tem apenas o que aprender. Em vez do monólogo, em vez da "aula expositiva", em vez da transmissão de conteúdos, a postura inicial de Sócrates, impactante pelo contraste, convida o interlocutor - incita-o, provoca-o - a travar conversação. Sócrates dá-lhe a palavra, elogiando-o...

9 XENOFONTE. Ditos e feitos memoráveis de Sócrates. In: Sócrates. Tradução de Líbero Rangel de Andrade. 2. ed. São Paulo: Abril Cultural, 1980 (Os Pensadores).

${ }^{10}$ Não confundir esta loucura com aquela que Sócrates (Platão) considera boa - efeito do favor divino, matriz da sabedoria...: Fedro, 244 a. 
A postura inicial de Sócrates tem uma intenção determinada que faz parte do conceito de ironia socrática. Duas intenções, melhor dizendo. Primeira: soltar a língua do interlocutor, levá-lo, por meio de perguntas habilmente conduzidas, a externar suas convicções sobre o assunto em tela. Ressalte-se que o interlocutor, aos seus próprios olhos e aos do público, é uma pessoa que ou domina determinados conceitos ou representa, de forma típica, determinada virtude (a coragem, a justiça, a piedade...). Em qualquer caso, a conversa de Sócrates diz respeito à suposta área de competência e desempenho prático do seu interlocutor. Posto isto, vamos à segunda intenção da ironia socrática: apanhar o interlocutor de tal maneira em contradições (Platão, Sofista, 230 b-c), insuficiências teóricas, escassez de rigor... que, de correção em correção, tome finalmente consciência, exausto de recursos, da extrema dificuldade da matéria em pauta - e se reconheça ignorante. Continuará refletindo sobre o assunto? Apartar-se-á de Sócrates, odiando-o $^{11}$ ?

A fase da conversa, em que, uma a uma, as respostas do interrogado vão-se mostrando insatisfatórias, dado o modo de Sócrates encaminhá-la, argumentando, é denominada elenchos ('é̉ $\varepsilon \gamma \chi 0 \varsigma$ ), refutação. Correspondelhe o conceito de catarse, purificação, cura espiritual... Segundo a maior parte dos scholars contemporâneos, esta fase é a que melhor caracteriza o método socrático.

Mas há um segundo aspecto importante do método: trata-se da maiêutica (arte de partejar). A alma, para Sócrates, somente conhece a verdade se dela está grávida, se a tem em germe. Contudo é preciso que nasça... O papel de Sócrates é ajudar a idéia a nascer. O discípulo dá à luz, desentranha a idéia, com o auxílio de Sócrates. Sócrates mesmo não tem verdades, não tem conhecimentos que transmitir ao discípulo. Este, em vez de ensinado, é instigado a descobrir em si, no curso do diálogo, a idéia procurada. É despertado dramaticamente para o conhecimento de si mesmo.

Já agora estamos longe do que os sofistas pretendem e prometem!

\footnotetext{
${ }^{11}$ Registre-se que o termo ironia, infreqüente nos textos platônicos, não é de Sócrates; é daqueles que Sócrates, no andamento dos diálogos, confunde, atenaza...
} 
Do ponto de vista do método enquanto ironia, a modéstia de Sócrates é suscitação ao diálogo e questionamento do pseudo-saber do interpelado. Além de fingir que não sabe, Sócrates finge que ignora a ignorância do outro... e aperta-o com argumentos.

Do ponto de vista do método enquanto maiêutica, a modéstia de Sócrates significa: Sócrates não tem conteúdos que repassar ou transmitir; o conceito que nasce não procede da sua alma (Platão, Teeteto, 150b - 151); preexiste à intervenção do interpelante.

Ora, isto não diminui o valor de Sócrates. Segundo o mesmo Sócrates, a busca da verdade requer a presença ativa do outro, mesmo que este nada comunique. A busca dá-se no diálogo, na conversação, na entrefala ${ }^{12}$. Assim, a forma literária (o diálogo) está unida à doutrina, embora, segundo a mesma doutrina, o dizível não substitua o encontro espiritual com o conceito, não substitua a contemplação.

A questão da modéstia socrática adensa-se e torna-se ainda mais complexa se atendemos ao que Sócrates, perante o tribunal ateniense, em 399 a.C., alega como sendo o motivo original das suas perambulações: o oráculo de Delfos. A sacerdotisa do templo, falando pela divindade, teria dito a Querefonte: "Não há homem mais sábio do que Sócrates". Confuso, perplexo (Que significarão estas palavras? Que sentido oculto guardarão?), Sócrates começa a interrogar, um por um, os que, na cidade, cidadãos ou forasteiros, se consideram detentores de algum saber. Objetivo: averiguar o oráculo $^{13}$. Desta interpelação crítica Sócrates conclui ser, com efeito, mais sábio que todos os homens ouvidos, pois, não sabendo eles realmente coisa nenhuma, presumem, entretanto, de sábios, ao passo que Sócrates, se nada sabe, sabe ao menos isto com segurança e firmeza: que nada sabe, que tem tudo a aprender.

Aplicar-se-á este conceito de igual modo a todos os diálogos platônicos em que Sócrates atua como personagem?

\footnotetext{
${ }^{12}$ Ver também a metáfora do espelho, a metáfora dos olhos, no Primeiro Alcibíades 132c133.

${ }^{13}$ Oráculo significa tanto a resposta de um deus a uma consulta como a própria divindade que responde, direta ou indiretamente, à consulta e orienta o consultante.
} 
Não. Aplica-se sobretudo aos primeiros e aos mais próximos dos primeiros. A maiêutica, especificamente, será tematizada depois, no Teeteto e no Mênon.

Escapa ao âmbito destas páginas acompanhar a trajetória intelectual de Sócrates, desde o abandono das explicações naturalistas até o que Platão nos transmite, em seus escritos posteriores, sobre o filósofo do "só sei que nada sei”. Benoit (Benoit, 1996, p. 44ss), reportando-se à Apologia, vê nas palavras "só sei que nada sei" a passagem, o começo da passagem, do puro não-saber, o "saber negativo", ao pleno e puro saber, o "saber positivo". O conteúdo afirmativo do "só sei que nada sei", diz Benoit, virá mais tarde com as revelações da sacerdotisa Diotima, sob cujo nome, no diálogo Banquete, Sócrates desenvolve o seu próprio discurso. É quando o "saber que nada sabe" ganha as asas de Eros... Eleva-se. Pois Eros também é um intermediário. Nascido da relação amorosa entre o rico deus Poros (póros significa abertura, passagem - daí, em português, os poros do corpo humano, da madeira...) e a deusa Penia (pénia significa indigência, pobreza - daí, em português, penúria), Eros alcovita, digamos assim, o estado aporético (sem saída) da ausência total do saber ao estado da sabedoria plena, absoluta, que é própria dos deuses. Força mediadora, comunica os dois mundos. Pondo-se entre o sensível e o supra-sensível, pondo-se entre, é capaz de aproximar opostos, é capaz, neste caso, de articular "insciência" e "pleno conhecimento racional" (Platão, Banquete, p. 202a-203e).

Por sua ascendência materna, Eros é pobre, rude, feio... Segundo o pai, entretanto, Eros é audaz, enérgico, volta-se para o que é belo, está sempre em busca da sabedoria...

Eros filosofa?

Pertence ao contexto a frase: "Nenhum deus filosofa ou deseja ser sábio - pois já é -, assim como, se alguém mais é sábio, não filosofa. Nem também os ignorantes filosofam ou desejam ser sábios..." (Platão, Banquete, p. 204a). 
O filósofo, para este Sócrates, está a meio caminho do saber e do nãosaber. Não se conforma com o não-saber. Inquieta-se, deseja. Deseja superar limites. Deseja a sabedoria. Fará este esforço de ascensão a ela.

A partir de certo momento, acrescenta Benoit, Sócrates se torna verdadeiro mestre espiritual. Passa a ter o que Benoit chama "saber verdadeiro e afirmativo", passa provavelmente a ter seguidores, dispostos, por sua vez, a "tentar a difícil ascensão até a idéia suprema do belo" (Benoit, 1996, p. 53).

Estaríamos ainda com o Sócrates histórico?

Eis como descreve Benoit o procedimento de Sócrates, já no Górgias: Sócrates não se limita a questionar, a contradizer; ele escacha os interlocutores, expondo teses, defendendo-as com veemência, ditando previamente as regras da conversação e cobrando dos interlocutores a estrita observância destas regras - que ele próprio, contudo, no mesmo diálogo, não cumpre de maneira fiel. Sócrates, continua o professor Benoit, “já não será tolerante com seus interlocutores": corta-lhes a palavra, desqualificaos... De fato, no final do diálogo, o que temos, em vez de interlocutores, são ouvintes: "Sócrates pronuncia um monólogo". No texto do professor Benoit, a exposição deste assunto leva o título "O saber dogmático" (Benoit, 1996, p. 54-59).

Perdeu-se a modéstia socrática?

Não, não se perdeu, respondemos nós, se a considerarmos como um recurso heurístico do método.

Se não absolutizarmos, pela descontextualização, o chamado nãosaber de Sócrates...

\section{O filósofo sabe}

O filósofo sabe... O filósofo não acha nada, o filósofo sabe... Em filosofia não há lugar para opiniões...

Hegel:

Uma opinião é uma representação subjetiva, um pensamento qualquer, uma fantasia que eu posso ter dum modo e outros de outro modo; uma opinião é 
coisa minha, nunca é uma idéia universal que exista em si e por si. Mas a filosofia não contém nenhuma opinião: não existem opiniões filosóficas [...]. $\mathrm{O}$ oposto da opinião é precisamente a verdade, e diante da verdade empalidece a opinião (Hegel, 1974, p. 51).

Kant:

No respeitante à certeza, a lei que impus a mim próprio obriga-me a que, nesta ordem de considerações, de modo algum seja permitido emitir opiniões e tudo o que se pareça com uma hipótese seja mercadoria proibida, que não se deve vender, nem pelo mais baixo preço, mas que urge confiscar logo que seja descoberta (Kant, 1994, p. 7) ${ }^{14}$.

\section{Arrogância do filósofo?}

Acoimado justamente de arrogante por atribuir-se o que, segundo ele mesmo, filósofo nenhum antes dele conseguiu (elevar a filosofia à categoria de "ciência evidente"), Fichte defende-se... como? com a distinção filosófica episteme e doxa, ciência e opinião:

Nas acusações de arrogância, feitas tão freqüentemente contra mim e contra outros defensores da doutrina-da-ciência, foi esquecido precisamente o ponto mais execrável de nossas presunções, a saber, que com toda a seriedade temos a pretensão de possuir e ensinar ciência - eu digo: ciência. Aqueles que narram uns aos outros suas opiniões têm de ser tolerantes e corteses entre si. Pois a opinião do outro pode muito bem ter tanto valor quanto a sua. Entre eles se diz: viver e deixar viver, conjeturar e deixar conjeturar. Eles têm de ser modestos na forma exterior porque no essencial são completamente arrogantes, pois é a mais monstruosa das arrogâncias acreditar que importa algo para o outro saber o que nós opinamos. Mas alguém cuja ciência - que não é nunca assunto dos indivíduos, e sim propriedade de todo o reino da razão - deva ser modesta para com a ignorância, é uma das coisas que nunca pude conceber. Logo, tudo depende unicamente de saber se nossa pressuposição - de que possuímos ciência - é correta. Decida-se primeiro algo quanto a isto, sem seguida, o mesmo se dará quanto à arrogância (Fichte, 1980, p. 195) ${ }^{15}$.

Ora, o conceito que Fichte faz das filosofias anteriores à dele (sendo a dele, finalmente, ciência) justifica a seus próprios olhos que elas se digam modestas. Não são apenas aspiração, busca, sképsis? Não são apenas FILOsofias? Melhor mudar o nome, porquanto a procura acabou.

\footnotetext{
${ }^{14}$ Os itálicos pertencem ao original.

${ }^{15}$ Os itálicos pertencem ao original.
} 
Se até agora, com a palavra filosofia, se pensou justamente isso [o que o autor está chamando, como obra sua, ciência] ou não, absolutamente não vem ao caso; mas então essa ciência, desde que se tivesse tornado ciência, deixaria de lado, não sem razão, um nome que até agora trazia por uma modéstia nada exagerada - o nome de um amadorismo, de um virtuosismo, de um diletantismo. A nação que encontrar essa ciência mereceria dar-lhe um nome tirado de sua língua; ela poderia então chamar-se simplesmente die Wissenschaft [a ciência] ou die Wissenschaftslehre (a doutrina-da ciência) (Fichte, 1980, p. 14, 15) ${ }^{16}$.

Logo quando Fichte diz "Eu acreditava, e acredito ainda, ter descoberto o caminho pelo qual a filosofia deve elevar-se ao estatuto de ciência evidente. Anunciei-o MODESTAMENTE..."(Fichte, 1980, p. 39) ${ }^{17}$, esta modéstia deve ser a do filósofo - afinal Fichte não aceitaria a idéia da modéstia associada à verdade em face da opinião...

Temos, assim, que a cada passo o tema da modéstia assedia e desinquieta os filósofos ou os comentadores das doutrinas filosóficas. Por quê? Por que esta necessidade de eternamente se explicarem os filósofos sobre o fôlego teórico das doutrinas que concebem? Por que nas explicações dadas temos quase sempre este vaivém, esta alternância de álibis, este deslizar do discurso ao sujeito, das razões aos motivos, dos gestos teóricos às provocações ad hominem, que as mesmas doutrinas eloqüentemente condenam $^{18}$ ?

\footnotetext{
${ }^{16}$ Isto, note-se bem, alguns anos antes de Hegel declarar, no prefácio à Fenomenologia do espírito: "Colaborar para que a filosofia se aproxime da forma da ciência - da meta em que deixe de chamar-se amor ao saber para ser saber efetivo - é isto o que me proponho" (Hegel, 2008: 27 - itálicos originais) e mais de cem anos antes de Husserl assegurar, por sua vez, em célebre artigo da revista Logos: a filosofia ainda não se estabeleceu como "ciência rigorosa" (Husserl, 1910/1911: 289-341). É, aliás, o que o próprio Husserl se dispõe a tentar.

${ }^{17}$ A ênfase das maiúsculas é nossa.

${ }^{18}$ Considere-se a declaração seguinte, do mesmo Fichte: "Minha marcha é integralmente demonstrativa, constitui uma única cadeia ininterrupta de raciocínio. Tudo aquilo que se segue, de cada vez, só é verdade para ti sob a condição de que tenhas encontrado como verdadeiro aquilo que, de cada vez, o precede. A partir daquele ponto que não tivesses encontrado como verdadeiro, não poderias mais pensar como eu pensei e a continuação da leitura, nessas circunstâncias, não teria para ti nenhum outro proveito, senão saberes o que eu havia pensado. Mas esse proveito é algo que sempre considerei muito insignificante, e sempre me espantei com a MODÉSTIA da maioria dos homens em atribuírem um valor tão alto ao pensamento dos outros e tão pequeno aos seus próprios, que preferem gastar a vida na freqüentação dos primeiros a engendrar por si mesmos alguns; uma MODÉSTIA que eu, em relação a meus pensamentos, proíbo terminantemente" (Fichte, 1980: 203, 204). Maiúsculas (MODÉSTIA) por nossa conta. Itálico (saberes) do original.
} 
Com efeito, quando a crítica transfere para a pessoa do filósofo (chamando-o de inapetente ou afoito) a suposta timidez teórica ou a suposta intemperança teórica do discurso produzido, o filósofo desvia da sua pessoa o dedo acusador, remetendo-o às pretensões (para menos ou para mais) da sua doutrina, tal como tematizadas e justificadas na própria doutrina remetendo-o, enfim, à verdade das mesmas teses que, formuladas por ele, provocam o comentário crítico.

Tomemos de novo a Crítica da razão pura.

No prefácio da primeira edição, após enunciar o que a obra se propõe (“a solução do problema da possibilidade ou impossibilidade de uma metafísica em geral e a determinação tanto das suas fontes como da sua extensão e limites"), após dizer que, havendo feito este caminho, se sente "lisonjeado por ter conseguido eliminar todos os erros que até agora tinham dividido a razão consigo mesma, no seu uso fora da experiência" até o ponto de "não haver um só problema metafísico que não se resolva aqui, ou, pelo menos, não encontre neste lugar a chave da solução", acrescenta o filósofo:

Ao falar assim, julgo perceber na fisionomia do leitor um misto de indignação e desprezo por pretensões aparentemente tão vaidosas e imodestas; e, contudo, são incomparavelmente mais moderadas do que as de qualquer autor do programa mais vulgar, que pretende, por exemplo, demonstrar a natureza simples da alma ou a necessidade de um primeiro começo do mundo; realmente, tal autor assume o compromisso de estender o conhecimento humano para além de todos os limites da experiência possível, coisa que, devo confessá-lo com humildade, ultrapassa inteiramente o meu poder; em vez disso, ocupo-me unicamente da razão e do seu pensar puro e não tenho necessidade de procurar longe de mim o seu conhecimento pormenorizado, pois o encontro em mim mesmo e já a lógica vulgar me dá um exemplo de que se podem enunciar, de maneira completa e sistemática, todos os atos simples da razão. O problema que aqui levanto é simplesmente o de saber até onde posso esperar alcançar com a razão, se me for retirada toda a matéria e todo o concurso da experiência (Kant, 1994, p. 6-7) ${ }^{19}$.

Tem aí o leitor juntas, uma ao lado da outra, a idéia de vaidade e a de imodéstia, postas em contraposição à de pretensão moderada. Tem aí o leitor como Kant, prevendo e prevenindo a acusação de presunçoso, se defende: ele compara sua filosofia com as outras do ponto de vista da

\footnotetext{
${ }^{19}$ Itálicos do original.
} 
ambição dos projetos e, dando como verdadeira uma das proposições centrais de sua própria doutrina, afirma que os outros programas assumem “o compromisso de estender o conhecimento humano para além de todos os limites da experiência possível”. Isto, continua o filósofo de Königsberg, "devo confessar com humildade que ultrapassa inteiramente o meu poder". Tem aí finalmente o leitor em que termos (irônicos, certamente, pois uma das teses do próprio Kant é que a razão teórica não é capaz desta proeza - e isto vale, segundo Kant, também para as outras filosofias) o filósofo se confessa humilde ${ }^{20}$.

Com efeito, a "revolução copernicana" de Kant não é apenas a tese de que o objeto se regula pelo conhecimento. Não é apenas a tese de que o objeto só existe em função da faculdade sintética do espírito humano. É também a afirmação de que as filosofias clássicas, além de realistas, são ingênuas. Por que ingênuas ou dogmáticas? Porque, diz Kant, não fazem a crítica da razão: não põem em questão ou põem em questão insuficientemente as possibilidades da razão conhecedora. A "viragem copernicana" é, portanto, na direção do conhecimento humano, e esta ênfase antropológica, antropológico-epistemológica, marca o pensamento moderno antes mesmo de Kant. As obras mais conhecidas de Locke, Berkeley e Hume são ensaios ou investigações sobre o entendimento humano, suas origens, sua natureza..., seu alcance.

Baste-nos Locke:

Ampliando suas investigações além de suas capacidades, e deixando seus pensamentos vagarem em profundezas, a tal ponto de lhes faltar apoio seguro para o pé, não é de admirar que os homens levantem questões e multipliquem disputas acerca de assuntos insolúveis, servindo apenas para prolongar e aumentar suas dúvidas, e para confirmá-los ao fim num perfeito ceticismo (Locke, 1978, p. 141).

Se por esta investigação acerca da natureza do entendimento puder descobrir seus poderes, até onde penetram, para que coisas estão em algum grau ajustados, e onde nos são deficientes, suponho que isso pode servir para persuadir a ocupada mente do homem e usar mais cautela quando se envolve com coisas que excedem sua compreensão, parar quando o assunto é muito

\footnotetext{
${ }^{20}$ Comparar no mesmo prefácio: "Não dei, é certo, àquelas questões as respostas que o exaltado desejo dogmático de saber desejaria esperar, pois é impossível satisfazê-lo de outra forma que não seja por artes mágicas, das quais nada entendo". p. 6.
} 
extenso para suas forças e permanecer em silenciosa ignorância acerca dessas coisas que o exame revelou estarem fora do alcance de nossas capacidades. Não seríamos, talvez, tão precipitados, devido à presunção de um conhecimento universal, a ponto de levantarmos questões, e de nos confundirmos e aos outros com disputas sobre coisas para as quais nossos entendimentos não são adequados e das quais não podemos formar em nossas mentes quaisquer percepções claras e distintas, ou de que (como tem, talvez, acontecido com muita freqüência) não temos de modo algum quaisquer noções. Se pudermos descobrir até onde o entendimento pode se estender, até onde suas faculdades podem alcançar a certeza, e em quais casos ele pode apenas julgar e adivinhar, saberemos como nos contentar com o que é alcançável por nós nesta situação (Locke, 1978, p. 140).

Referindo-se justamente à filosofia moderna, a encíclica Fides et Ratio, de João Paulo II, diz que

a filosofia moderna, esquecendo-se de orientar a sua pesquisa para o ser, concentrou a própria investigação sobre o conhecimento humano. Em vez de se apoiar sobre a capacidade que o homem tem de conhecer a verdade, preferiu sublinhar as suas limitações e condicionalismos (João Paulo II, 2002, p. $\S 5)^{21}$.

Por que esta súbita referência à encíclica de João Paulo II, tão distante dos tempos de Locke? Porque a encíclica, reprovando o que ela vê como decorrências daquele modo de pensar, emprega as palavras falsa modéstia:

Como conseqüência, despontaram, não só em alguns filósofos mas no homem contemporâneo em geral, atitudes de desconfiança generalizada quanto aos grandes recursos cognoscitivos do ser humano. Com falsa modéstia, contentam-se de verdades parciais e provisórias, deixando de tentar pôr as perguntas radicais sobre o sentido e o fundamento último da vida humana, pessoal e social.

Aos olhos das filosofias clássicas, aos olhos dos que se intitulam seus legítimos representantes nos dias modernos e contemporâneos (o tomismo entraria aqui), a filosofia atual surge como indigente e restringidora, do mesmo modo como, aos olhos de muitos filósofos modernos, as filosofias clássicas se apresentam como ingenuamente pretenciosas $^{22}$.

\footnotetext{
${ }^{21}$ Curiosamente, "dúvidas sobre a adequação de nosso equipamento para atingir a verdade anunciaram-se pela primeira vez no contexto religioso em contraste com a claridade da visão divina"... (Guthrie, 1995, p. 13).

${ }^{22}$ Atenção! Segundo o tomismo atual, é falso que o ponto de vista crítico, em filosofia, tenha aparecido somente com os modernos. Diz Jolivet: "Para a razão é natural interrogar-
} 
E hoje? Diz o professor Torres Filho, levantando provocativamente aspectos novos da questão:

Quem não notou a inquietante modéstia que leva os que lidam com filosofia hoje a se esquivarem da denominação de filósofos? São, no máximo, "estudantes de filosofia", "professores de filosofia", "historiadores da filosofia" (Dizem: - "Eu mexo com filosofia..."), elevando a uma segunda potência aquele mesmo pudor, talvez, que levava os antigos a se chamarem de philosophoi, os amigos da sabedoria, e não sophoi, não diretamente "os sábios". Neste jogo de humildade e presunção, que não deixa de evocar certas análises hegelianas, reconhece-se aqui um tique semântico que não perde seu interesse (antes pelo contrário) quando se nota que sua origem é milenar. Do fundo de que astúcia provém esta relutância em aderir a uma qualificação, muito ambiciosa, talvez, ou determinada demais? Pois dá a entender que a ciência do filósofo - se é que se pode falar assim, por hipótese - ou está no topo de todas as outras, ou é utópica por excelência: ciência cujo sujeito tende sempre a recuar em relação a ela, ou a ficar à deriva, como os antigos diante da Sophia, os modernos diante da própria Philo-sophia. Chegou o tempo dos filo-filósofos? (Torres Filho, 2004, p. 1920).

\section{O filósofo sabe?}

Os sujeitos "que lidam com a filosofia" podem ser tanto os que a estudam, divulgam, lecionam, perfilham... quanto os autores mesmos, os produtores intelectuais das doutrinas, aqueles a cujos nomes a preposição de antecede em frases como "filosofia de Nietzsche", "filosofia de Sartre"... Não há filosofia sem filósofo.

Também não há discurso científico (ciência positiva) sem o autor, o sujeito (conhecido ou não) do discurso -, mas, neste caso, o sentido filosófico da preposição de é outro, ainda quando, em vez de enviar o discurso aos seus referentes (lei $d a$ oferta e $d a$ procura, fórmula estrutural $d o$ benzeno...), a preposição o remete àquele que por primeiro, ou de maneira mais assinalada, o enunciou: teoria de Newton, leis de Mendel, hipótese de Avogrado, conjectura de Goldbach, princípio de Arquimedes, teorema de Pitágoras (o nosso Pitágoras!), geometria de Euclides... Em que sentido isto: "Os planetas descrevem órbitas elípticas um de cujos focos é ocupado pelo

se a respeito de seu valor e de seu alcance, e desde a antiguidade esse problema foi formulado, estudado, senão resolvido, com uma clareza perfeita. Se o problema crítico tomou, na idade moderna, novas formas, nada prova a priori que haja nisto um progresso verdadeiro, nem que a solução geral deste problema dependa de princípios diferentes daqueles que a antiguidade e a Idade Média puseram em prática” - JOLIVET, 1965: 38. 
Sol” é de Kepler? Quanto perde o último teorema de Fermat, demonstrado três séculos e meio depois da sua formulação original, se ficar provado que Fermat nunca existiu e não é dele o teorema?

Trata-se de saber se, em filosofia, sucede com a verdade o mesmo que sucede nas ciências positivas, onde a verdade, uma vez encontrada, se incorpora na disciplina estabelecida, subtraindo-se assim ao seu inventor. O teorema demonstrado é do domínio público (Gusdorf, 1960, p. 8).

Por outro lado, chamaremos imodesto ao autor da fórmula $E=m c^{2}$ pela amplitude do campo que ela abrange, pelo avanço que representa ou pelo alcance extraordinário das suas aplicações?

A diferença entre a objetividade possível do discurso científico e a objetividade possível, buscada ou não, pretendida ou não, de direito ou não, do discurso filosófico talvez esteja na origem da dificuldade em distinguir, sem mediações, sem meias-tintas, a modéstia do filósofo e a modéstia $d a$ filosofia que o filósofo assume como de sua própria lavra, de sua própria autoria e concepção. Quanto a nós entendemos que o assunto pode perfeitamente ser discutido sem qualquer condescendência ao psicologismo, ao sociologismo, aos subjetivismos reducionistas de toda sorte, às falácias genéticas de toda sorte - o que é diferente de negar a historicidade do discurso, a dimensão psicológica, social, cultural dos sujeitos, filósofos ou não.

Mas há outras dificuldades, ainda que nos cinjamos ao conteúdo expresso do discurso.

Afirma a doutrina $\mathrm{Y}$ sobre a doutrina $\mathrm{Z}$ (doutrinas filosóficas): “A doutrina $\mathrm{Z}$ é muito restrita, desambiciosa; subestima os grandes recursos cognitivos do ser humano"... Afirma a doutrina Z sobre a doutrina Y: "A doutrina $\mathrm{Y}$ é exorbitante, desmedida; superestima as possibilidades cognitivas do ser humano"... Perguntamos nós: a partir de que ponto a doutrina filosófica deixa de ser moderada e demasia-se, torna-se excessiva, no que entende com seus marcos teóricos? Onde passam os limites legítimos da nossa compreensão racional da realidade? Quanto pode a razão filosófica? 
As filosofias dão respostas diferentes a esta questão. Rigorosamente nem mesmo os termos da questão têm o mesmo sentido de filosofia para filosofia.

Em cada caso a resposta é parte integrante da doutrina que responde; é uma das suas teses. A resposta nunca é filosoficamente neutra e, assim, no todo ou em parte, também não será aceita pelas doutrinas diferentes; no todo ou em parte será por elas criticada.

Ponhamos um exemplo.

Dando início à sua obra $O$ estruturalismo e a miséria da razão (Coutinho, 1972), obra profundamente inspirada na de Lukács Die Zerstörung der Vernunft, assevera o professor Coutinho que, do Renascimento a meados do século XIX, temos na filosofia (acompanhando a evolução do capitalismo nascente e refletindo o ser social mais complexo, mais articulado, que a nova ordem germina e faz nascer) um movimento progressista, no qual os representantes ideológicos da burguesia revolucionária, comprometidos com o progresso, proclamam no que diz respeito à razão "seu ilimitado poder de apreensão do mundo" (p. 12). A síntese hegeliana, na filosofia, seria o ponto culminante deste processo, seria a reafirmação, em posição maximamente elevada para o seu tempo, das grandes conquistas teóricas dos tempos anteriores: o historicismo - a afirmação do caráter ontologicamente histórico da realidade humana -, o humanismo - a afirmação do homem como produto da sua própria atividade histórica e coletiva -, e a razão dialética - a afirmação da realidade como um todo racional, cujo conhecimento e domínio constituem uma possibilidade aberta à razão humana. As leis racionais a que a realidade se subordina podem ser apreendidas integralmente por nosso pensamento (p. 8). Ou seja, há uma racionalidade objetiva, imanente ao desenvolvimento da realidade, e o homem, por sua vez, é capaz de captar subjetivamente, de modo pleno, esta racionalidade objetiva (ponto de vista da totalidade).

Após Hegel, após o conturbado período histórico em que a burguesia se torna uma classe conservadora e rompe, senão com a totalidade do pensamento anterior, pelo menos com seu núcleo progressista, a filosofia 
correspondente entra a decompor-se; a razão passa a ser "encarada com um ceticismo cada vez maior, renegada como instrumento do conhecimento ou limitada a esferas progressivamente menores ou menos significativas da realidade" (p.9).

O texto do professor Coutinho, neste capítulo inicial, menciona como objetos exemplares e merecidos da crítica a filosofia de Kierkegaard, a de Dilthey, a de Nietzsche, o neokantismo, o neo-hegelianismo, o positivismo comtiano, o estruturalismo - assunto principal da obra --, a fenomenologia (Husserl, o primeiro Sartre...), o existencialismo, o neopositivismo... e Foucault $^{23}$.

Como respondem estas filosofias, expressa ou subentendidamente, à crítica? Respondem, primeiro, concordando que a razão abraçada por elas é mais modesta que a razão hegeliana. De fato é outra razão. Diversifica o conceito - e talvez não sejam, no conjunto, apenas dois, como entende Horkheimer, invocado pelo professor Coutinho. Umberto Eco adverte-nos que seria difícil definir "irracionalismo" sem dispor de um conceito filosófico de razão. Infelizmente, continua,

toda a história da filosofia ocidental serve para provar que tal definição é muito controvertida. Qualquer forma de pensar sempre é vista como irracional pelo modelo histórico de outra forma de pensar, que vê a si mesmo como racional. A lógica de Aristóteles não é a mesma que a de Hegel; Ratio, Ragione, Raison, Reason e Vernunft não significam a mesma coisa (Eco, 1993, p. 30).

Para nós [sublinha Cassirer, abrindo a apresentação do Iluminismo] a palavra "razão" deixou de ser há muito tempo uma palavra simples e unívoca. Assim que recorremos a esse vocábulo, sua história logo revive em nós e ficamos cada vez mais conscientes da gravidade das mudanças de sentido que ele sofreu no transcurso dessa história (Cassirer, 1994, p. 23) 24. $^{24}$

Respondem, além disto, as filosofias criticadas, justificando-se, ou seja, argumentando. TODAS as filosofias, sem exceção das que se

\footnotetext{
${ }^{23}$ Schopenhauer, contemporâneo direto de Hegel - O mundo como vontade e representação é de 1819 -, crítico de Hegel, mais jovem que Kierkegaard, não é citado neste capítulo, aliás nem na história da filosofia de Hegel, segundo a qual, com Fichte, Schelling e principalmente com o próprio Hegel, a história da filosofia se encerra: "não existem outras filosofias" - HEGEL,1995: 460, 461, 517.

${ }^{24}$ A ênfase dos itálicos é do original.
} 
expressam por fórmulas breves e aforismos, argumentam, mesmo que não demonstrativamente. Não há filosofia sem aposição de razões.

Respondem, por fim e por seu turno, criticando. Além de se criticarem umas às outras, as filosofias mencionadas pelo professor Coutinho criticam a de Hegel, inclusivamente, e até principalmente, naqueles aspectos da doutrina hegeliana que o professor Coutinho considera os mais preciosos. Não há filosofia sem oposição de razões. Acontece, porém, que a crítica filosófica também não é filosoficamente neutra. Depende da doutrina a partir da qual, à luz da qual, em nome da qual a crítica é feita. A crítica de Aristóteles às filosofias que vêm antes da dele é aristotélica o tempo todo. A crítica de Descartes às filosofias que vêm antes da dele é cartesiana desde os princípios. A crítica de Heidegger às filosofias que vêm antes da dele é heideggeriana já na linguagem... A crítica é como um braço da doutrina de origem: tem o mesmo DNA... No fundo é doutrina contra doutrina.

Se, por exemplo, rendendo-nos às teses principais do positivismo lógico, tacharmos as teses principais da filosofia hegeliana de sem-sentido (menos que falsas: destituídas de sentido - radicalidade da crítica filosófica!), estaremos amplamente escudados na lógica do positivismo lógico do Círculo de Viena, substanciada na obra de Russell e Whitehead Principia mathematica, que, por sua vez, incorpora contribuições de Frege, Peano, Schröder... (Russell, 1910, 1912, 1913). Ora, esta não é a lógica de Hegel...

... nem a de Kierkegaard, um dos primeiros nomes aduzidos pelo professor Coutinho como representante do "pensamento fetichizado", imediatista, subjetivista, direitista, servil aos interesses da burguesia decadente, alienado, reacionário e destruidor da Razão. Que dizer da réplica de Kierkegaard ao sistema hegeliano?

As objeções a Hegel adquirirão no pensamento deste autor [Kierkegaard] uma profundidade e uma radicalidade poucas vezes vista [radicalidade da crítica filosófica!]. Tal como o engenheiro que, visando pôr abaixo uma construção, deve dinamitar suas fundações, o crítico de uma filosofia sistemática como a hegeliana não deve se preocupar com elementos laterais, 
mas com as bases do sistema. Pois essa é a atitude de Kierkegaard (Luft, 2001, p. 47,48$)^{25}$.

Ora, um dos aspectos visados pela crítica de Kierkegaard a Hegel é justamente o gigantismo, o descomedimento de suas pretensões ("Cômica a situação do espírito sistemático, que acredita poder dizer tudo..." Kierkegaard). À "razão quase enlouquecida", "quixotesca" de Hegel (Konder, $1991^{26}$ ), que "lê os mandamentos divinos diretamente no original", opõe Kierkegaard uma visão de mundo que o professor Coutinho chama pobre, apoucada..., mas não faltaria quem chamasse modesta - e a elogiasse por sua adequação.

Quanto pode a razão humana?

De que lugar filosófico resolveremos este assunto ${ }^{27}$ ?

Coexistem, sucedem-se as filosofias, diferentes no que tange às suas teses (entre elas, a do método geral de conhecimento do objeto e mesmo a de qual seja este objeto no caso das filosofias), diferentes no que tange aos critérios (entre eles o próprio critério da verdade, segundo o qual cada filosofia avalia as outras e exige ser por elas avaliada), diferentes no que tange ao vocabulário, aos conceitos básicos (daí os dicionários de filosofia e seus verbetes)...

\footnotetext{
${ }^{25}$ Comparar Marx e Engels que afirmam, na Ideologia alemã, contra certos opositores do sistema hegeliano: longe de irem às bases filosóficas gerais do sistema, longe de lhe fazerem uma crítica de conjunto, tomam-no por assentado, limitando a crítica a aspectos particulares do sistema, como, por exemplo, as representações religiosas (Marx; Engels, 2007, p. 39). A passagem do idealismo ao materialismo não é uma passagem qualquer...

26 "Nas condições atuais, não podemos nos iludir a respeito dessa 'mania de grandeza' que parece transparecer da concepção hegeliana da razão dialética. A dialética, em nossos dias, sente necessidade de se dialetizar mais a si própria: é mais modesta, mais autocrítica".

${ }^{27}$ Aqui estamos considerando estritamente as respostas filosóficas. Mas há outros lugares de resposta. Há, por exemplo, a resposta da psicanálise freudiana à nossa pergunta. Opondo a psicanálise a toda forma de Weltanschaung, Freud, o da maturidade, aproxima do delírio paranóico a filosofia; aproxima-a, "tanto na forma como na expressão", da discursividade obsessiva, da esquizofrenia... A ambição de dominar o real e racionalizá-lo, diz Freud, perigosa para a razão em geral e para a pesquisa científica em particular, é de fundo mágico, anímico; revive o mito primitivo da organicidade do universo. Ora, "é sempre a filosofia de Hegel o alvo teórico visado por Freud, caracterizado seja pela pretensão totalizante, seja pela pretensão a ser um sistema" (Birman, 2003: 50). Sobre esta aproximação entre as filosofias da totalidade, maiormente a de Hegel, e a idéia, no fundo religiosa, da unidade primigênia perdida, contudo recuperável, entre o sujeito e o objeto, contra todas as formas de alheiamento e alienação, ver Nuño, 1985: cap. IV.
} 
Não coincidindo as filosofias nem sequer na identificação da instância em que se dá a profundidade máxima das coisas (ou, correspondentemente, na do limite do discurso que se apresenta como recuado ao limite), alguém talvez contraponha ao nosso o desafio seguinte: de que lugar EXTERIOR e ANTERIOR à radicalidade pretendida das doutrinas filosóficas seria editada a resposta decisiva à nossa pergunta?

Tragam isto ao autor destas linhas e ele dirá as primeiras palavras da Apologia socrática:- Não sei.

Mas, desta vez, seguramente, sem os favores de Eros.

\section{Referências}

ARISTÓTELES. Da geração e da corrup̧ão. Tradução de Renata Maria Pereira Cordeiro. São Paulo: Landy, 2001.

ARISTÓTELES. Ética a Nicômaco. Tradução de Antônio de Castro Caeiro. São Paulo: Atlas, 2009.

BENOIT, H. Sócrates: o nascimento da razão negativa. São Paulo: Moderna, 1996.

BIRMAN, J. Freud \& a filosofia. Rio de Janeiro: Jorge Zahar, 2003.

BURKERT, W. Platon oder Pythagoras. Zum Ursprung des Wortes "Philosophie". Hermes, 88, p. 159-177, 1960.

CASSIRER, E. A filosofia do Iluminismo. Tradução de Álvaro Cabral. 2. ed. Campinas: Ed. da UNICAMP, 1994.

CICÉRON. Tusculance disputationes. In: CICÉRON. CEuvres philosophiques. Texte établi par Georges Fohlen et traduit par Jules Humbert. Paris: Société d'Édition "Les Belles Lettres", 1931, t. I.

COUTINHO, C. N. O estruturalismo e a miséria da razão. Rio de Janeiro: Paz e Terra, 1972.

DIELS, H. A.; KRANZ, W. Die Fragmente der Vorsokratiker. Berlin: Weidmann, 1952.

DIÔGENES LAÊRTIOS. Vidas e doutrinas dos filósofos ilustres. Tradução, introdução e notas de Mário da Gama Kury. 2. ed. Brasília: Ed da UnB, 1977 [original provavelmente do século III d.C.].

ECO, U. Interpretação e superinterpretação. Tradução de M. F. São Paulo: Martins Fontes, 1993. 
FICHTE. $A$ doutrina-da-ciência de 1794. In: FICHTE. $A$ doutrina-da-ciência de 1794 e outros escritos. Seleção de textos, tradução e notas de Rubens Rodrigues Torres Filho. São Paulo: Abril Cultural, 1980 (Os Pensadores).

FICHTE. Comunicado claro como o sol ao grande público onde se mostra em que consiste propriamente a novíssima filosofia: um ensaio para forçar o leitor à inteligência. In: FICHTE. A doutrina-da-ciência de 1794 e outros escritos. Seleção de textos, tradução e notas de Rubens Rodrigues Torres Filho. São Paulo: Abril Cultural, 1980 (Os Pensadores).

FICHTE. O programa da doutrina-da-ciência.In: FICHTE. A doutrina-da-ciência de 1794 e outros escritos. Seleção de textos, tradução e notas de Rubens Rodrigues Torres Filho. São Paulo: Abril Cultural, 1980 (Os Pensadores).

FICHTE. Sobre o conceito da doutrina-da-ciência ou da assim chamada filosofia. In: FICHTE. A doutrina-da-ciência de 1794 e outros escritos. Seleção de textos, tradução e notas de Rubens Rodrigues Torres Filho. São Paulo: Abril Cultural, 1980 (Os Pensadores).

FRANCA, L. Noções de história da filosofia. 21. ed. Rio de Janeiro: Agir, 1973.

GUSDORF, G. Tratado de metafísica. Tradução de António Pinto de Carvalho. São Paulo: Nacional, 1960.

GUTHRIE, W. K. C. Os sofistas. Tradução de João Rezende Costa. São Paulo: Paulus, 1995.

HEGEL. Fenomenologia do espirito. Tradução de Paulo Meneses, com a colaboração de Karl-Heinz e José Nogueira Machado, SJ. 5. ed. Petrópolis/Bragança Paulista: Vozes/Un. São Francisco, 2008.

HEGEL. Introdução à história da filosofia. Tradução de António Pinto de Carvalho. 3. ed. Coimbra: Armênio Amado, 1974.

HEGEL. Lecciones sobre la historia de la filosofia. Tradução de Wenceslao Roces. México: Fondo de Cultura Económica, 1995.

HERÔDOTOS. História. Tradução, introdução e notas de Mário da Gama Kury. 2. ed. Brasília: Ed. Unb, 1988.

HUSSERL, E. Philosophie als strenge Wissenschaft. Logos, Tübingen, I, 2, 1910/1911.

JOÃO PAULO II. Fides et Ratio. Carta encíclica aos bispos da Igreja católica sobre as relações entre fé e razão. 6. ed. São Paulo: Paulinas, 2002.

JOLIVET. R. Tratado de filosofia. Tradução de Maria da Glória Pereira Pinto Alcure. Rio de Janeiro: Agir, 1965; tomo III (Metafísica). 
KANT. Crítica da razão pura. Tradução de Manuela Pinto dos Santos e Alexandre Fradique Morujão. 3. ed. Lisboa: Fundação Calouste Gulbenkian, 1994.

KENNY, A. Uma nova história da filosofia ocidental. São Paulo: Loyola, 2008, v. 1 (Filosofia Antiga).

KONDER, L. Hegel: a razão quase enlouquecida. Rio de Janeiro: Campus, 1991.

LALANDE, A. Vocabulário técnico e crítico da filosofia. Tradução de Fátima Sá Correia, Maria Emília V. Aguiar, José Eduardo Torres e Maria Gorete de Souza. 2. ed. São Paulo: Martins Fontes, 1996.

LITTRÉ, E. Dictionnaire de la langue française. Paris: Hachette, 1889, tomo 3.

LOCKE, J. Ensaio acerca do entendimento humano. In: LOCKE. Carta acerca da tolerância. Segundo tratado sobre o governo. Ensaio acerca do entendimento bumano. Tradução de Anoar Aiex e E. Jacy Monteiro. 2. ed. São Paulo: Abril Cultural, 1978 (Os Pensadores).

LUFT, E. As sementes da dúvida: investigação crítica dos fundamentos da filosofia hegeliana. São Paulo: Mandarim, 2001.

MAGALHÃeS-VILHENA, V. de. Pequeno manual de filosofia. 5. ed. Lisboa: Sá da Costa, 1977.

MALINGREY, A.-M. Philosophia: étude d'un groupe de mots dans la littérature grecque des prèsocratiques au IV ème siècle aprés J-C. Paris: Klincksieck, 1961.

MARX, K.; ENGELS, F. A ideologia alemã. Organização, tradução, prefácio e notas de Marcelo Backes. Rio de Janeiro: Civilização Brasileira, 2007.

MARITAIN, J. Introdução geral à filosofia. Tradução de Ilza das Neves e Heloísa de Oliveira Penteado. 15 ed. Rio de Janeiro: Agir, 1987.

MORENTE, M. G. Fundamentos de filosofia. Tradução de Guilhermo de la Cruz Coronado. 4. ed. São Paulo: Mestre Jou, 1970.

NUÑO, J. Los mitos filosóficos. México: Fondo de Cultura Económica, 1985.

PLATÃO. Apologia de Sócrates. In: PLATÃO. Diálogos III. Tradução, textos complementares e notas de Edson Bini. Bauru: EDIPRO, 2008.

PLATÃO. A república. Tradução, textos complementares e notas de Edson Bini. Bauru: EDIPRO, 2006.

PLATÃO. Banquete. In: PLATÃO. Diálogos V. Tradução, textos complementares e notas de Edson Bini. Bauru: EDIPRO, 2010. 
PLATÃO. Fédon. In: PLATÃO. Diálogos III. Tradução, textos complementares e notas de Edson Bini. Bauru: EDIPRO, 2008.

PLATÃO. Teeteto. In: PLATÃO. Diálogos I. Tradução, textos complementares e notas de Edson Bini. Bauru: EDIPRO, 2007.

RUSSELL, B.; WHITEHEAD, A. N. Principia mathematica. Cambridge: Cambridge University Press, 1999.

THUCYDIDES. The Peloponnesian War. Cambridge: Cambridge University Press, 1999.

TORRES FILHO, R. R. Ensaios de filosofia ilustrada São Paulo: Iluminuras, 2004.

XENOFONTE. Ditos e feitos memoráveis de Sócrates. In: Sócrates. Tradução de Líbero Rangel de Andrade. 2. ed. São Paulo: Abril Cultural, 1980 (Os Pensadores). 